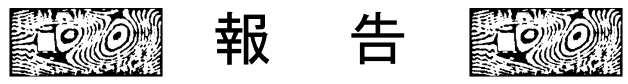

\title{
立川俱子様からのご寄附について \\ On Contribution from Tomoko Tachikawa
}

平成 18 年に故立川正夫先生の令夫人である立川俱子様から ご寄附いただき, 本会ではこのご寄附を表彰事業準備金として, 平成 20 年度から日本風工学会研究奨励賞を受賞した若手研究 者に立川研究奨励金を贈呈してまいりました。今般，立川俱子
様から表彰事業準備金に加えていただきたいと，新たにご寄附 を頂戴いたしましたのでご報告いたします。本会はこのご寄附 を表彰事業準備金に繰入れ，立川研究奨励金として運用いたし ます。立川俱子様にはご厚意に厚く御礼申し上げます。

平成 23 年 11 月 30 日

一般社団法人日本風工学会

会長河井宏允 